\section{PARTICULAR UTILITY OF THE HMBC TECHNIQUE TO POLYPROPIONATE DERIVED METABOLITES AS EXEMPLIFIED BY ERYTHROMYCIN A}

Sir:

Recently a new 2D NMR technique named Heteronuclear Multiple Bond Connectivity (HMBC) was reported by BAX et al. ${ }^{1 \sim 3)}$ This method reveals ${ }^{13} \mathrm{C}$ and ${ }^{1} \mathrm{H}$ connectivities separated by two or three bonds through detection of cross peaks observed with ${ }^{1} \mathrm{H}$ nucleus. Since
Fig. 1. The structure of erythromycin A.

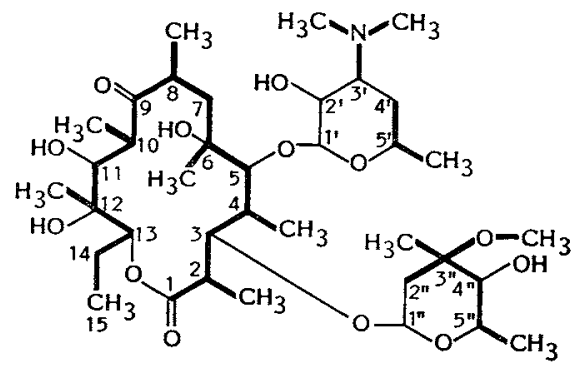

Bold lines show the connectivities revealed by analysis of the $\mathrm{HMBC}$ spectrum.

Fig. 2. The pertinent region of the HMBC spectrum of erythromycin $A$ (in $C_{6} D_{6}$ ).

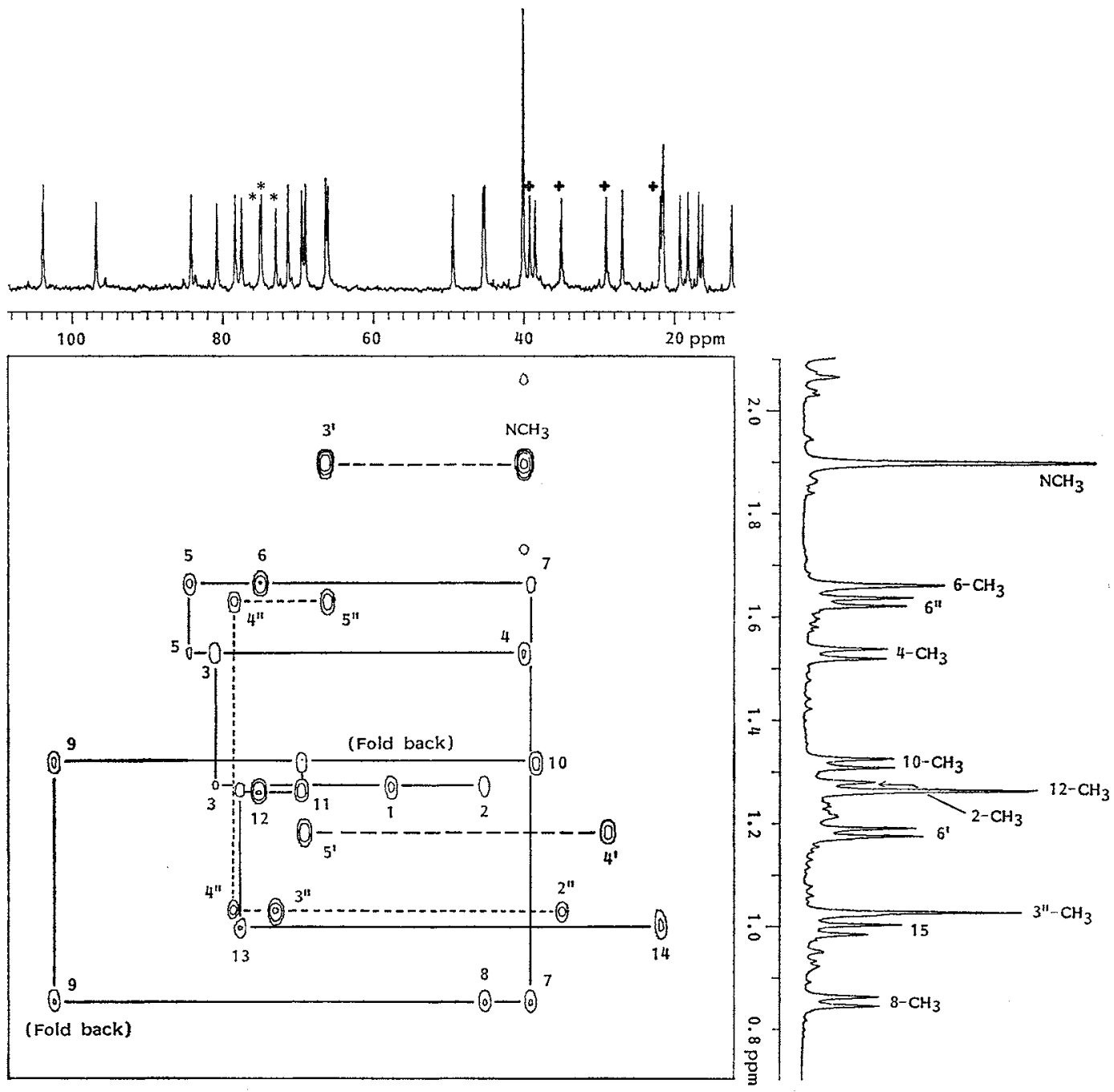

+ and * represent methylene and quaternary carbons, respectively. The remaining signals below $30 \mathrm{ppm}$ are due to methine carbons. 
the sensitivity of this method is dependent on the signal intensities of the proton signals, its application to polyketide antibiotics such as macrolides and polyethers with many methyl groups, which are observed as strong sharp signals in the ${ }^{1} \mathrm{H}$ NMR spectra, is highly promising as evidenced by our previous work..$^{4,5)}$

Another advantage of the application of HMBC for structural studies of complicated molecules with many methyl groups is that the cross peaks of the methyl carbons can be very easy analyzed, since the carbon next to a methyl residue (i.e. $\left.{ }^{2} J_{\mathrm{O}-\mathrm{H}}\right)$ is easily identified by analysis of ${ }^{1} \mathrm{H}^{-1} \mathrm{H}$ correlation spectroscopy (COSY) and ${ }^{13} \mathrm{C}-{ }^{1} \mathrm{H}$ COSY spectra. Thus, the distinction of ${ }^{2} J_{\mathrm{O}-\mathrm{H}}$ and ${ }^{3} J_{\mathrm{O}-\mathrm{H}}$, which is very difficult in most cases, can easily be accomplished.

In this paper, we wish to report the application of $\mathrm{HMBC}$ to the assignment of the ${ }^{13} \mathrm{C}$ NMR spectrum of erythromycin A (Fig. 1).

Fig. 2 shows the HMBC spectrum of erythromycin $A$ dissolved in $C_{6} D_{8}$. In order to improve digital resolution, the relevant region of ${ }^{13} \mathrm{C}$ NMR spectrum $\left(\delta_{\mathrm{C}} 10 \sim 110\right)$ was measured resulting in folding over of the ester (C-1, appeared at $\delta_{\mathrm{C}} 175.9$ in the $1 \mathrm{D}{ }^{13} \mathrm{C} \mathrm{NMR}$ spectrum) and ketone $\left(\mathrm{C}-9\right.$, appeared at $\delta_{\mathrm{c}} 220.6$ in the ${ }^{13} \mathrm{C}$ NMR spectrum) resonances, which are observed at approximately 58 and $102 \mathrm{ppm}$, respectively. Analysis of this spectrum could be made very straightforwardly. For example, a methyl proton doublet at $\delta_{\mathrm{H}} 1.27\left(2-\mathrm{CH}_{3}\right)$ showed cross peaks with an ester carbonyl (observed as a fold back signal at $\left.c a . \delta_{\mathrm{c}} 58(\mathrm{C}-1)\right)$, a methine at $\delta_{\mathrm{o}}$ $45.4(\mathrm{C}-2)$ and an oxymethine at $\delta_{\mathrm{C}} 80.8(\mathrm{C}-3)$, which are unambiguously assigned to the partial structure, $\mathrm{OOC} 1-\mathrm{C} 2 \mathrm{H}\left(\mathrm{CH}_{3}\right)-\mathrm{C} 3 \mathrm{H}(\mathrm{O})$ by taking account of their ${ }^{13} \mathrm{C}$ chemical shifts. The direct combination of this methyl group to the non oxygenated methine $\left(\delta_{\mathrm{H}} 3.0, \delta_{\mathrm{C}} 45.4(\mathrm{C}-2)\right)$ was based on analysis of ${ }^{1} \mathrm{H}-{ }^{-1} \mathrm{H}$ COSY and ${ }^{13} \mathrm{C}^{1} \mathrm{H}$ COSY spectra (data not shown).

As shown in Fig. 2, another cross peak is observed between $\mathrm{C}-3$ and a methyl doublet at $\delta_{\mathrm{H}} 1.525\left(4-\mathrm{CH}_{3}\right)$, which shows additional cross peaks with a methine $\left(\delta_{\mathrm{C}} 40.1(\mathrm{C}-4)\right)$ and an oxymethine $\left(\delta_{\mathrm{O}} 84.2(\mathrm{C}-5)\right)$. These results proved the connectivity of $\mathrm{C} 3 \mathrm{H}(\mathrm{O})-\mathrm{C} 4 \mathrm{H}\left(\mathrm{CH}_{3}\right)$ $\mathrm{C} 5 \mathrm{H}(\mathrm{O})$ extending the relationship from $\mathrm{C}-1$ to $\mathrm{C}-5$. The complete connectivity of the carbon skeleton of the aglycone moiety (C-1 to C-15) could easily be established by repeating the same procedure. In addition, the connectivities $\mathrm{C}^{\prime \prime} \mathrm{H}_{2}-\mathrm{C}^{\prime \prime}\left(\mathrm{CH}_{3}\right)\left(\mathrm{OCH}_{3}\right)-\mathrm{C}^{\prime \prime} \mathrm{H}(\mathrm{O})-$ $\mathrm{C}^{\prime \prime} \mathrm{H}(\mathrm{O})-\mathrm{CH}_{3}$ (shown by dotted lines) in cladinose, and $\left(\mathrm{CH}_{3}\right)_{2} \mathrm{~N}-\mathrm{C}^{\prime} \mathrm{H}$ and $\mathrm{C}^{\prime} \mathrm{H}_{2}-$

Table 1. ${ }^{13} \mathrm{C}$ Chemical shifts of erythromycin.

\begin{tabular}{lr|lr}
\hline \multicolumn{1}{c|}{ Carbon } & \multicolumn{1}{c}{$\delta_{\mathrm{C}}$} & \multicolumn{1}{c}{ Carbon } & $\delta_{\mathrm{C}}$ \\
\hline $\mathrm{C}-1(\mathrm{COO})$ & 175.9 & $\mathrm{C}-1^{\prime}(\mathrm{O}-\mathrm{CH}-\mathrm{O})$ & 103.8 \\
$\mathrm{C}-2(\mathrm{CH})$ & 45.4 & $\mathrm{C}-2^{\prime}(\mathrm{CH}-\mathrm{O})$ & 66.3 \\
$\mathrm{C}-3(\mathrm{CH}-\mathrm{O})$ & 80.8 & $\mathrm{C}-3^{\prime}(\mathrm{CH}-\mathrm{N})$ & 29.1 \\
$\mathrm{C}-4(\mathrm{CH})$ & 40.1 & $\mathrm{C}-4^{\prime}(\mathrm{CH})$ & 69.0 \\
$\mathrm{C}-5(\mathrm{CH}-\mathrm{O})$ & 84.2 & $\mathrm{C}-5^{\prime}(\mathrm{CH}-\mathrm{O})$ & 21.6 \\
$\mathrm{C}-6(\mathrm{C}-\mathrm{O})$ & 74.9 & $\mathrm{C}-6^{\prime}\left(\mathrm{CH}_{3}\right)$ & 40.1 \\
$\mathrm{C}-7(\mathrm{CH})$ & 39.2 & $\mathrm{~N}-\mathrm{CH}_{3}$ & 96.8 \\
$\mathrm{C}-8(\mathrm{CH})$ & 45.2 & $\mathrm{C}-1^{\prime \prime}(\mathrm{O}-\mathrm{CH}-\mathrm{O})$ & 35.0 \\
$\mathrm{C}-9(\mathrm{C}=\mathrm{O})$ & 220.6 & $\mathrm{C}-2^{\prime \prime}(\mathrm{CH})$ & 72.9 \\
$\mathrm{C}-10(\mathrm{CH})$ & 38.5 & $\mathrm{C}-3^{\prime \prime}(\mathrm{C}-\mathrm{O})$ & 78.3 \\
$\mathrm{C}-11(\mathrm{CH}-\mathrm{O})$ & 69.4 & $\mathrm{C}-4^{\prime \prime}(\mathrm{CH}-\mathrm{O})$ & 66.0 \\
$\mathrm{C}-12(\mathrm{C}-\mathrm{O})$ & 75.0 & $\mathrm{C}-5^{\prime \prime}(\mathrm{CH}-\mathrm{O})$ & 19.3 \\
$\mathrm{C}-13(\mathrm{CH}-\mathrm{O})$ & 77.5 & $\left.\mathrm{C}-6^{\prime \prime}(\mathrm{CH})_{3}\right)$ & 21.5 \\
$\left.\mathrm{C}-14(\mathrm{CH})_{2}\right)$ & 21.9 & $3^{\prime \prime}-\mathrm{CH}_{3}$ & 49.4 \\
$\mathrm{C}-15(\mathrm{CH})$ & 11.1 & $\mathrm{O}-\mathrm{CH}_{3}$ & \\
$2-\mathrm{CH}_{3}$ & 16.3 & & \\
$4-\mathrm{CH}_{3}$ & 9.6 & & \\
$6-\mathrm{CH}_{3}$ & 26.9 & & \\
$8-\mathrm{CH}_{3}$ & 18.2 & & \\
$10-\mathrm{CH}_{3}$ & 12.4 & & \\
$12-\mathrm{CH}_{3}$ & 16.8 & & \\
\hline
\end{tabular}

Taken in $\mathrm{C}_{6} \mathrm{D}_{6}$. 
$\mathrm{C}^{\prime} \mathrm{H}(\mathrm{O})-\mathrm{CH}_{3}$ (shown by broken lines) in desosamine are also revealed as shown in Fig. 2. The connectivities revealed by analysis of the HMBC spectrum are indicated by bold lines in Fig. 1.

In addition to the structural information just explained, the HMBC spectrum revealed the relationships between $1^{\prime}-\mathrm{H}$ and $\mathrm{C}-5,1^{\prime}-\mathrm{H}$ and $\mathrm{C}-5^{\prime}, 1^{\prime \prime}-\mathrm{H}$ and $\mathrm{C}-3$, and $1^{\prime \prime}-\mathrm{H}$ and $\mathrm{C}-5^{\prime \prime}$ (data not shown). However, the linkage between $\mathrm{C}-1$ and $\mathrm{C}-13$ through an oxygen could not be proved due probably to the very small long range coupling $\left({ }^{3} J_{\mathrm{O}-\mathrm{H}}\right)$ between $13-\mathrm{H}$ and $\mathrm{C}-1$. Additional structural information such as $\mathrm{Cl}^{\prime \prime}$ $\mathrm{C}^{\prime \prime}$ and $\mathrm{C}^{\prime}-\mathrm{C}^{\prime}-\mathrm{C}^{\prime}-\mathrm{C} 4^{\prime}$ could also be obtained by HMBC. These connectivities, however, were more easily obtained by usual ${ }^{1} \mathrm{H}$ NMR techniques such as COSY.

These results show clearly the particular usefulness of HMBC for structural elucidation of complicated antibiotics with many methyl groups.

In order to get good results by HMBC experiments, it is important to choose a solvent which gives good separation of methyl signals. As far as our experiences are concerned, $\mathrm{C}_{8} \mathrm{D}_{6}$ or pyridine- $d_{5}$ gave better results than $\mathrm{CDCl}_{3}$ in most cases.

The ${ }^{13} \mathrm{C}$ chemical shift data thus obtained are summarized in Table 1. In view of the difference of the solvent employed in this experiment, this assignment is in good agreement with those reported previously ${ }^{\theta \sim 9)}$

The experimental conditions were as follows; spectral width $\mathrm{F}_{1}\left({ }^{13} \mathrm{C}\right) 10,000 \mathrm{~Hz}, \mathrm{~F}_{2}\left({ }^{1} \mathrm{H}\right) 3,000$ $\mathrm{Hz}$, data matrix $\left(\mathrm{F}_{1} \times \mathrm{F}_{2}\right)=128 \times 1,024\left(\mathrm{~F}_{1}\right.$ data were zero filled prior to Fourier transformation), 240 scans per $t_{1}$, total measuring time 14 hours. The sample $(10 \mathrm{mg})$ was dissolved in $0.35 \mathrm{ml}$ of $\mathrm{C}_{6} \mathrm{D}_{6}$.

\section{Acknowledgments}

This work was supported by a Grant-in-Aid for Developmental Scientific Research, The Ministry of Education, Science and Culture, Japan (62860014 to H.S.).

Haruo Seto
Kazuo Furihata
Muneki OHuchi $^{\dagger}$

Institute of Applied Microbiology, The University of Tokyo, Bunkyo-ku, Tokyo 113, Japan 'Jeol Co., Akishima, Tokyo 196, Japan

(Received March 17, 1988)

\section{References}

1) Summers, M. F.; L. G. Marzilli \& A. BaX: Complete ${ }^{1} \mathrm{H}$ and ${ }^{13} \mathrm{C}$ assignments of coenzyme $B_{12}$ through the use of new two-dimensional NMR experiments. J. Am. Chem. Soc. 108: 4285 4294, 1986

2) BAx, A. \& M. F. Summers: ${ }^{1} \mathrm{H}$ and ${ }^{13} \mathrm{C}$ assignments from sensitivity-enhanced detection of heteronuclear multiple-bond connectivity by $2 \mathrm{D}$ multiple quantum NMR. J. Am. Chem. Soc. 108: 2093 2094, 1986

3) Bax, A.; A. Aszalos, Z. Dinya \& K. Sudo: Structure elucidation of the antibiotic desertomycin through the use of new two-dimensional NMR techniques. J. Am. Chem. Soc. 108: 8056 8063, 1986

4) Seto, H.; K. Furihata, K. Saeki, N. Otake, Y. Kusak.abe, C. Xu \& J. Clardy: Structural studies of natural products by new NMR techniques. The structure of a new polyether antibiotic, portmicin. Tetrahedron Lett. 28: $3357 \sim 3360,1987$

5) Seto, H.; K. Furihata, X. Guangyi, C. Xiong \& P. Des: Assignments of the ${ }^{1} \mathrm{H}$ and ${ }^{13} \mathrm{C}-\mathrm{nmr}$ spectra of four lycopodium triterpenoids by application of a new two-dimensional technique, Heteronuclear Multiple Bond Connectivity (HMBC). Agric. Biol. Chem. 52: 1797 1801, 1988

6) EVERETT, J. R. \& J. W. TYLER: An analysis of the ${ }^{1} \mathrm{H}$ and ${ }^{13} \mathrm{C}$ n.m.r. spectra of erythromycin A using two-dimensional methods. J. Chem. Soc. Perkin Trans. I 1985: 2599 2603, 1985

7) Cane, D. E.; H. Hasler \& T.-C. Liang: Macrolide biosynthesis. Origin of the oxygen atoms in the erythromycins. J. Am. Chem. Soc. 103: 5960 5962, 1981

8) Ōmura, S.; A. Neszmélyi, M. Sangaré \& G. LukACs: Conformational homogene ty in solution of 14-membered macrolide antibiotics as evidenced by ${ }^{13} \mathrm{C}$ NMR spectroscopy. Tetrahedron Lett. 1975: 2939 2942, 1975

9) Terui, Y.; K. Tori, K. Nagashima \& N. Tsuis: C-13 nuclear magnetic resonance spectra of erythromycins. Tetrahedron Lett. 1975: 2583 2586,1975 